\title{
IMPACTS OF EXTENSION TRAINING PROGRAMMES ON POULTRY FARMERS IN NIGERIA: PRIVATE FARM EXPERIENCE
}

\author{
aOghenero Ovharhe*, aPeter Emaziye, bSamson Alakpa, aFolorunsho Alli \\ ${ }^{a}$ Department of Agricultural Economics and Extension, Delta State University, Asaba Campus, Asaba, Delta State, Nigeria. \\ ${ }^{b}$ Benson Idahosa University, Benin City, Edo State, Nigeria.
}

\section{ART I CLE IN F O}

\section{Article History}

Received: June 01, 2021

Revised: August 01,2021

Accepted: August 25, 2021

\section{Keywords}

Extension training

programmes

Poultry

Farmers

Impacts

\section{A B S T R A C T}

This study appraised the impact of the training programme (such a feed formulation, house preparation, brooding vaccination schedule, stocking density, litter application, types sorting and handling of eggs, record keeping and accounts) given to poultry farmers by the private sector. Obasanjo Farms Nigeria Limited was used as a case study. The study objectives were to investigate the sources of the information about the training programmes, identified training needs of participants, capture adoption techniques, ascertained training satisfaction level, ascertained property acquisition of beneficiaries before and after the training and identify constraints facing the participants. A simple random sampling technique was used for this study to obtain a sample size of 84 . A set of questionnaires was used to elicit information from respondents. Data obtained were analyzed statistically. The study revealed that the majority (82.1\%) were males with a mean age of 30years and mean the farming experience was two years. The major source of information was radio (52.4\%). Training need such as feed formulation (66.9\%) optimal on needs assessment rating. The majority (at medium level) adopted the training rendered on feed formulation, stocking density, brooding techniques, and medication techniques. Respondents were mostly satisfied with training given on brooding (mean $=3.4$ ). The most serious constraint was the inadequate provision of starter packs to trainees. On before and after comparison, the T-test showed that there were significant differences between the various properties acquired after the training programme $(\mathrm{p}<0.05)$. The study concluded that trainees were satisfied with the training as it contributed to increased wellbeing. It was recommended that trainees should be equipped after training sessions to ensure best practices and food security.

Corresponding Author: Oghenero Ovharhe

Email: drovharhe.oghenero@gmail.com

(C) The Author(s) 2021.

\section{INTRODUCTION}

Poultry farming holds promises for the ready provision of the quality amount of protein to the most hungerstricken and mal-fed factions more effectively than raising cattle on pastures. The word poultry is mostly used to address chicken or domestic fowl, which is the most common avian species raised in most developing countries such as Nigeria for either meat or for eggs, which are both for human consumption. Amongst poultry birds, chickens are raised in great numbers and also the most numerous of all poultry birds. More than 50 million chickens are raised annually as a ready source of food of both table meat and eggs in most developing countries (World Bank, 2010). The poultry 
practice has many branches which include eggs and meat production; poultry feed formulation and compounding, processing, marketing and commercial sale of eggs and table birds. Poultry production in all its ramifications represents one of the most viable and productive forms of the farming enterprise, providing the much-needed animal protein sources to ameliorate the protein shortage factor in the Nigerian food crisis. Raheem (2011) asserted that poultry production is faced with many problems, such as the high cost of feeding and veterinary drugs, poor quality of commercial feeds due to abuses from the manufacturers, little or no capital investment and poor knowledge on the nutrients and energy requirements of various classes of poultry birds. This culminates in low production and subsequently reduced income which frustrates the business venture and sometimes leads to financial bankruptcy (Aromolarun, 1999).

Traditional poultry farming is generally subsistence in the outlook without the use of modern scientific methods and procedures as prevalent in neighbourhood farming (Oghenero et al., 2020). Hence the birds under this system are poorly cared for and they are characterized by a slow growth rate, poor feed utilization and low productivity. The birds are also exposed to high mortality rates as a result of disease, pests and bad weather conditions (I-Project, 2015).

Poultry productivity advancement is guaranteed with adequate training programmes for poultry business practitioners. Extension training programme in the agricultural sphere is concerned with constant educating of farmers with new agricultural innovations and methods. Leagans (1990) described extension training programme as an applied science that consists of contents derived from various research, accumulated from countless field practice and relevant principles derived from behavioral sciences and some focused on the problems of out of school education for youths and adults. He also said that "extension training programme is the process of teaching rural farmers on how to live better through the learning of ways and methods that improves their farms and communities".

Agricultural extension in poultry programme: Training is a term, which covers a wide range of activities. Its length could vary from short-term training activities such as periodic demonstrations concerning farmers' needs using professional courses which could last for an acceptable duration (FAO, 2002). Training is an important tool for assisting poultry farmers in the realization of their objectives and goals of rearing poultry birds. Often the farmers are faced with the need to change their techniques or to implement a new way of raising poultry birds. Agricultural extension training programmes may also need to provide farmers with new knowledge and /or with new skills that are necessary to implement a change. Training programmes on poultry is, therefore, a potential solution to the lack of skills and technical know-how of poultry farmers (FAO, 2002).

\section{Agricultural extension training programme}

Sanoria (2011) also describes extension training programme as a professional method of informal education which is aimed at impacting behavioural changes in farmers for increasing their income through improved productivity by establishing a strong and lasting bond with researchers for solving farmer's problems also ensuring regular and adequate supply of information and innovations using proven methods of communication for the rapid process of acceptance and adoption of innovations. He further stated on the point that extension training programme as the dissemination of information, knowledge and also innovations to farmers for the improvement of their rural life. Uzokwe and Ovharhe (2011) described the extensive training programme as a participatory network that disseminates scientific and indigenous knowledge, accessible information to the rural farmers and also expresses the problems of the farmers to research organizations for clarifications with feedback processes. The main aim of the training programme is to bring about an all-round growth, change and development for the rural farmer and his household. The all-round growth involves the educational, economic, social and political development inclusive. The extension programme is to bring about change in behaviour, attitude in a wider context and also in the work capacity of the rural farmer.

This aim can be archived through objectives such as training of rural youth for growth and development, improvement of the rural area at large, to improve the standard of leaving in these rural areas. Therefore, after all being said farmers adopt more and new methods, their idea changes, they develop a new and different attitude towards agriculture and the natural world that surrounds them. 


\section{Extension Training Methods}

The channel of communication is called the extension teaching method.

According to Rielly (2013), there is a wide range of training methods and aids available for utilization, it is not a question of either-or but which method is appropriate for a particular purpose at a specific time and in certain circumstances. The choice of method generally relies on the number and location of the target audience and the time available for communication. Farmers learn in different ways, some by listening, seeing, acting and others through discussions. People don't learn at the same speed, some may be at the stage of trying a new practice and want to know the details of how to do it, whereas others are barely aware of the practice or becoming interested, for these reasons the use of a variety of teaching method is most effective. Extension methods (Table 1) are categorized into three which are the individual method, group method, and mass method (Japan International Cooperation Agency, 2008).

Table 1. Classifications of extension training methods and techniques.

\begin{tabular}{lll}
\hline Individual Training Methods & Group Training Methods & Mass Training Methods \\
\hline Farms and home visitation & Method demonstrations & Projected media: Films, slides, in focus \\
\hline Office calls or Farmer's call & Result demonstrations & $\begin{array}{l}\text { Print media: Magazines, newsletters, } \\
\text { bulletins, and journals. }\end{array}$ \\
\hline Personal phone calls, emails and letters. & Small meeting groups & $\begin{array}{l}\text { Broadcast media: Television programs } \\
\text { and radio broadcast }\end{array}$ \\
\hline Adoptive on-farm trials & $\begin{array}{l}\text { Group meetings } \\
\text { Field trips and excursions. }\end{array}$ \\
\hline
\end{tabular}

Source: Japan International Cooperation Agency, JICA, (2008)

In achieving these various methods, there is a need for Training need assessment (TNA). TNA involves knowledge of the felt needs identification process. After which the following are necessary: preparation and design of training programme, deciding the appropriate training environment, proper planning and sequencing of the training programme activities, choosing the most effective training method and technique to deliver it and monitoring and evaluation stage to improve the training activity results in the future (FAO, 2002).

\section{Nature and Scope of Obasanjo Farms Nigeria Ogwashi-Uku, Delta State}

The Obasanjo farms Nigeria Ltd. situated in OgwashiUku, Delta State is a private sector farm that disseminates information about new technologies to farmers with formal or informal training. It focuses on enhancing farmers' knowledge about poultry farming techniques and helping them to increase productivity. This is done through training courses, on-farm trials, advisory bulletins and newsletters.

The Obasanjo Delta Farms Nigeria is an apex poultry farm that was set up by a one-time former President of the Federal Republic of Nigeria, Gen Olusegun Obasanjo in partnership with the Delta State Government. The farm is a poultry production farm that deals mainly in the rearing of day-old chicks to layer birds and compounding and formulating of poultry feeds. Since the creation of the farm in 2010 several training programmes on poultry practices have been carried out to impact its neighboring small-scale farmers with knowledge, experiences and technological know-how need to sustain their productivity and also to improve their wellbeing and livelihood. The farm is in partnership with the Delta State Government to build the capacity of poultry farmers and ensure employment and food security within the state and the country at large.

Every profitable enterprise poultry farming also has its challenges poultry is faced with a few challenges which could range from diseases affecting the birds to the problem of brooding, marketing problems, starting capital, gender role in poultry farming. Poultry farming is faced with a serious challenge, that is extension agencies and policymakers have not made or carried out adequate training programmes on poultry farming. Delta State, Nigeria has been known to be loan-supportive of rural and small-scale farmers so there is a great need for training programmes to be carried out since not much awareness has been created on poultry farming advisory services (Ovharhe, 2017). These constraints are reduced when farmers are trained and retrained to increase their awareness levels on contemporary farming techniques. On this premise, this study was designed with the 
following aims, to investigate the source of the information about the training programmes by the beneficiaries, identify the training needs of the farmers, Capture the level of adoption techniques, ascertain the level of satisfaction from the training programme, property acquisition of beneficiaries before and after the training and identify the constraints facing the farmers.

\section{Hypotheses}

Ho1: There is no significant difference between the socioeconomic characteristics of poultry farmers and the level of satisfaction in training programmes on the private farm.

$\mathrm{Ho}_{2}$ : There is no significant difference in the property acquisition of the farmers between before the training programme and after the training programmes on poultry farming.

\section{METHODOLOGY}

The study area was Delta State. Delta State lies approximately between Longitude $5^{\circ} 00$ and $6^{\circ} .45^{\prime}$ East and Latitude $5^{\circ} 00$ and $6^{\circ} .30^{\prime}$ North (Delta State, 2018). Delta State is made up of three (3) Agricultural Zones and twenty-five (25) Local Government Areas. A simple random sampling technique was used for this study. A total of 120 poultry farmers have been trained for the past six years (2013 - 2018). The training was conducted by agricultural graduates, farm manager and extension personnel. A sample of $70 \%$ of poultry farmers was randomly drawn from the total population of trained farmers to form a sample size of 84 . The sample was dominated by male youth poultry farmers of the Ministry of Agriculture and Rural Development. Data were collected from respondents with the aid of a structured questionnaire schedule. This questionnaire was distributed by trained enumerators. The questionnaire comprised various issues relating to the aim of the study.

\section{Measurement of variables}

The various variables were measured following acceptable standards. For instance, age and farming experience were measured in years. Sources of the Information about the training programme were measured by itemizing options from which respondents indicated as applicable. A dichotomous scale of "yes" and "no "was used to obtain the information needed from the respondents about their training needs. The level of adoption techniques was measured first by using a dichotomous scale of "yes" and "no". Followed by the sigma method as used by Agbamu (2006) and Ovharhe (2017). For instance, if $57.1 \%$ of farmers adopted the use of silage, the adoption score is calculated as follows: $100 \%$ - 57.1 divided by $2=71.5$. Next, using the statistical Table of normal derivative, 71 under 5 will be checked to give 0.568 . A constant 2 is added to the result and then multiplied by the same constant to increase the magnitude of the value from the Table of the normal derivative. In other words $(0.568+2)$ multiplied by 2 . Since the Sigma method of scoring assigns weights in a reverse relation on a 10-point scale, the actual adoption score will then be $10-5.14$ which equals 4.8. For this study a score ranging from $5.5-10.0$ will be considered as the high level of adoption; $4.1-5.4$ is the medium level of adoption and $0.0-4.0$ is the low level of adoption.

The levels of satisfaction from the training programme were achieved using a rating scale. A Likert-type scale of four (4) points was used to know the various satisfaction levels of the respondents. The statements were associated with the following response/weight "strongly agree (4)", "agree (3)", "disagree (2)", "and strongly disagree (1)" with a 2.5 mean cut-off point (Ovharhe et al., 2020). For property acquisition of beneficiaries before and after the training programme: A comparative numerical count was used to ascertain the quantity of household, farm assets, yields, farm size, and financial issues. The constraints facing the farmers were identified with the use of four (4) point Likert type- scale (as numerically applicable to the satisfaction scale) consisting of "very serious", "serious", "fairly serious", and "not serious" measurement was used in data analysis.

\section{Methods of Data Analysis}

The data which was gotten would be analyzed using the Statistical Package for Social Sciences (SPSS) application. Both descriptive and inferential statistics were used for the analysis of data. Descriptive statistics included frequency counts, means, and percentages which were used to realize the stated objectives which include socioeconomic characteristics, source of information, training needs of the respondents. Inferential statistical tools, Regression and Wilcoxon test were used to analyze hypotheses one and two respectively:

The various statistical approaches below were used for analysis: 


\section{Mean Calculation}

$X=\Sigma \frac{f i(A i)}{n}$

Where:

$\mathrm{X}=$ Mean Score

$F_{i}=$ Frequency or number of respondents

$A_{i}=$ Value Assigned to portions

$\mathrm{N}=$ Sample Size

$\Sigma=$ Summation

\section{Regression Analysis}

Hypothesis one was analyzed by Multiple Regression.

Linear, semi-log and double log forms of regression was used in the analysis. A lead equation was used to make a conclusion based on the relative magnitude of the $R^{2}$, relative Fcal value of the models and the function that showed more statistically significance. The linear Regression Equation is stated as;

$\mathrm{Y}=\mathrm{b}_{0}+\mathrm{b}_{1} \mathrm{X}_{1}+\mathrm{b}_{2} \mathrm{X}_{2}+\mathrm{b}_{3} \mathrm{X}_{3} \ldots \ldots \ldots+\mathrm{b}_{6} \mathrm{X}_{6}+\mathrm{e}$

Where,

$\mathrm{Y} \quad=\quad$ Farmers Satisfaction

$\mathrm{b} 0=$ Constant

b1 to b6 = Regression Coefficient of six Variables

$\mathrm{X} 1=$ Age of Farmers

$\mathrm{X} 2=$ Sex of Farmers

$\mathrm{X} 3=$ Marital Status of farmers

$\mathrm{X} 4=$ Educational Levels of the Famers

$\mathrm{X} 5=$ Farming Experience

$\mathrm{X} 6=$ Household Size e $\quad=\quad$ random error

Semi-log Functional Form of Regression

$\mathrm{Y}=\log \mathrm{b}_{0}+\mathrm{b}_{1} \log \mathrm{X}_{1}+\mathrm{b}_{2} \log \mathrm{X}_{2}+\mathrm{b}_{3} \log \mathrm{X}_{3} \ldots \ldots . .+\mathrm{b}_{6} \log \mathrm{X}_{6}+\mathrm{e}$

Double Log Functional Form of Regression

$\log \mathrm{Y}=\log \mathrm{b}_{0}+\mathrm{b}_{1} \log \mathrm{X}_{1}+\mathrm{b}_{2} \log \mathrm{X}_{2}+\mathrm{b}_{3} \log \mathrm{X}_{3} \ldots .+\mathrm{b}_{6} \log \mathrm{X}_{6}+\mathrm{e}$

The multiple regression analysis was engaged for this research.

The Wilcoxon test was used to analyze hypothesis two:

$Z=T-\frac{N(N+1)}{\frac{4}{\sqrt{\frac{N(N+1)(2 N+1)}{24}}}}$

Where $\mathrm{T}=$ Absolute Sum of the negative ranks and $\mathrm{N}=$ number of Performance indicators

\section{RESULTS AND DISCUSSION}

A summary of the socio-economic characteristics of the respondents is shown in Table 2. It shows clearly that the mean age of respondents was 36 and with males $(82.1 \%)$ who were single (48\%). Respondents (55\%) attained secondary school with a mean age of 7 years as farming experience. The implication is that more males and unmarried youths were beneficiaries of the programme. These findings tally with Ovharhe and Gbigbi (2016) who opined that active and unmarried youths were selected for a youth empowerment programme in Delta State. Again, Gbigbi and Ovharhe (2016) asserted that the better educated and experienced farmers are, the better their level of responses to training and adoption of new technologies.

Table 2. Socio-economic characteristics of the respondents in summary.

\begin{tabular}{ll}
\hline Socio-economic characteristics & Values \\
\hline Age: (mean in years) & 36 \\
Gender: (Male \%) & 81 \\
Marital status: (Single \%) & 48 \\
Educational Attainment: (Secondary School \%) & 55 \\
Farming Experience: (mean in years) & 7 \\
\hline
\end{tabular}

Source: Field Responses

\section{Source of information about the training programmes}

Table 3, shows that most of the respondents got information about the training programme through radio. This could be as a result of radio is the most widespread means of getting information to rural established farmers. This is similar to the findings of
Ebewore and Ovharhe (2019) that most farmers use their phones to get information as it is less expensive. It was noticed that both the government and private extension workers were the ranked least in rendering information to respondents. This implies that they might not be well equipped with information concerning the activities of Obasanjo Farms Ltd. 
Table 3. Respondents' source of training information (multiple responses, $\mathrm{n}=84$ ).

\begin{tabular}{lccc}
\hline Sources of Information & Frequency & Percentage & Rank \\
\hline Radio & 44 & 52.4 & $1^{\text {st }}$ \\
Friends & 41 & 48.8 & $2^{\text {nd }}$ \\
Internet & 37 & 44.0 & $3^{\text {rd }}$ \\
Television & 30 & 35.7 & $4^{\text {th }}$ \\
Contact Farmers & 27 & 32.1 & $5^{\text {th }}$ \\
Town Crier & 19 & 22.6 & $6^{\text {th }}$ \\
Government Extension Workers & 10 & 11.9 & $7^{\text {th }}$ \\
Private Extension Worker & 6 & 7.1 & $8^{\text {th }}$ \\
\hline
\end{tabular}

Source: Field Responses

Identifying the training needs of the farmers

Results in Table 4 show the level of the training needs required by poultry respondents. The topmost ranked felt need was feed formulation (67.9\%). Some donor agencies meeting the felt needs of farmers enable them to participate in farm activities with higher productivity as discovered in a participatory rural appraisal community needs assessment programme (Uzokwe and Ovharhe, 2011). The lowest-ranked in the profile need was record keeping. This connotes that it was an unserious need for the trainees compared to feed formulation which ranked first.

Table 4. Respondents' training needs (multiple responses, $\mathrm{n}=84$ ).

\begin{tabular}{lccc}
\hline Training Activities & Respondents (Yes) & Percentage & Rank \\
\hline Feed formulation & 57 & 67.9 & 1 st \\
House preparation & 55 & 65.5 & $2 \mathrm{nd}$ \\
Brooding & 54 & 64.3 & $3 \mathrm{rd}$ \\
Vaccination schedule & 45 & 53.6 & 4 th \\
Stocking density & 42 & 50.0 & 5 th \\
Litter application and types & 40 & 47.6 & 6 th \\
Sorting and handling of eggs & 38 & 45.2 & 7 th \\
Record keeping and account & 30 & 35.7 & 8 th \\
\hline
\end{tabular}

Source: Field Responses

\section{Level of adoption techniques by respondents}

Table 5 show various poultry techniques that were learned by respondents during the training programme and adopted after the programme in their various locations. The adoption of stocking density techniques of 5-8 birds per square meter was paramount by respondents together with brooding, feed formulation and medication techniques (60.7\%) though at the medium level (5.2) in the Sigma adoption scale. The overall adoption means score $=4.0$ (pooled adoption score).

This finding aligns with Ovharhe (2017) that poultry farmers had a medium level of adoption of recommended technologies by the Fadama III project in Delta State. Ovwigho (2013) reported that farmers providing farmers with adequate training and farm inputs as in the Fadama III project facilitate the adoption of innovations.

\section{Level of Satisfaction from the Training Programme}

Table 6 shows that respondents were greatly satisfied with the training as in brooding (mean=3.4), feed formulation (mean=2.8) and housing (mean=2.7) being uppermost at the ranking scale. These results were similar to the satisfaction level derived by poultry farmers in Delta State as reported by Ike (2012). However, respondents were least satisfied with the training given on tractor driving and maintenance (mean=2.1). This confirms the low usage of tractor farming in Delta State. 
Table 5. Respondents' level of techniques adoption $(\mathrm{n}=84)$.

\begin{tabular}{lccc}
\hline Techniques & Total no. of adopters and \% & Pooled adoption score & Adoption Level \\
\hline Stocking density & $51(60.7)$ & 5.2 & Medium \\
Brooding technique & $51(60.7)$ & 5.2 & Medium \\
Feed formulation & $51(60.7)$ & 5.2 & Medium \\
Medication technique & $51(60.7)$ & 5.1 & Medium \\
House construction & $50(59.5)$ & 4.9 & Medium \\
Vaccination technique & $49(58.3)$ & 5.1 & Medium \\
Litter management & $46(54.8)$ & 4.8 & Medium \\
Footbath & $42(50.0)$ & 4.6 & Medium \\
De-beaking & $42(50.0)$ & 4.6 & Medium \\
Record keeping & $39(46.4)$ & 4.5 & Medium \\
\hline
\end{tabular}

Overall Adoption Level $=4.0$

Source: Field Responses

Table 6. Respondents' satisfaction level from training programme $(\mathrm{n}=84)$.

\begin{tabular}{lccccccc}
\hline \multicolumn{1}{c}{ Level of Satisfaction } & $\begin{array}{c}\text { Strongly } \\
\text { Agreed } \\
(4)\end{array}$ & $\begin{array}{c}\text { Agreed } \\
(3)\end{array}$ & $\begin{array}{c}\text { Disagreed } \\
(2)\end{array}$ & $\begin{array}{c}\text { Strongly } \\
\text { Disagreed } \\
(1)\end{array}$ & $\begin{array}{c}\text { Total } \\
\text { Score }\end{array}$ & $\begin{array}{c}\text { Mean } \\
\text { Score }\end{array}$ & Rank \\
\hline Brooding & $47(188)$ & $24(72)$ & $10(20)$ & $3(3)$ & 283 & 3.4 & 1 st \\
Feed formulation & $26(104)$ & $25(75)$ & $26(52)$ & $7(7)$ & 238 & 2.8 & 2 nd \\
Housing & $11(44)$ & $42(126)$ & $28(56)$ & $3(3)$ & 229 & 2.7 & 4 th \\
Egg handling & $18(72)$ & $31(93)$ & $25(50)$ & $10(10)$ & 225 & 2.7 & 4 th \\
Vaccination & $12(48)$ & $34(102)$ & $34(68)$ & $4(4)$ & 222 & 2.6 & 6 th \\
Litter management & $14(56)$ & $33(99)$ & $26(52)$ & $11(11)$ & 218 & 2.6 & 6 th \\
De-beaking & $12(48)$ & $27(81)$ & $38(76)$ & $7(7)$ & 212 & 2.5 & 8 th \\
Record keeping & $10(40)$ & $31(93)$ & $29(58)$ & $14(14)$ & 205 & 2.4 & 9 th \\
Tractor Driving and Maintenance & $3(12)$ & $17(51)$ & $47(94)$ & $17(17)$ & 174 & 2.1 & 10 th \\
\hline
\end{tabular}

Note: $\quad$ Figures in parentheses are scores from Likert- type scale. Cut off mean $=2.5(\geq 2.5=$ Satisfied training; $<2.5$ unsatisfied training)

\section{Property Acquisition Before and After the Training programme}

Entries in Table 7 shows that there was a significant difference as there were increases in the number of litters used by the respondents, total bags of feed, total number of birds and also in the average income of the respondents after the training programme at the stage of implementation of technologies acquired. The training had positive impacts on respondents' wellbeing. This is at variance with those of Agbamu and Okagbare (2005) who asserted that farmers only performed well during the programme of the World Bank.

\section{Constraints facing the poultry farmers}

The result in Table 8 reveals that the major constraint faced by the respondent in the course of the training programme was the inadequate provision of starter packs at graduation by various sponsors $($ mean $=3.3$ ) .
The pooled mean $=2.6$. This suggests that the overall constraints were above average and serious for handling with applicable solutions for a sustainable poultry business. Ovharhe et al. (2020) complained that negligence in the handling of constraints facing peasant farmers, always results to decline in farm productivity. Secondly, the results in Table 10 shows that the computed indicators $=\mathrm{Zcal}$ is 3.30 , while Ztab at $\mathrm{p}=0.05$ is 1.65; thus, rejecting the null hypothesis. This implies that there were significant differences in property acquisition before and after the training programme and that because of the adoption of acquired skills and technologies farmers' wellbeing increased. This is in agreement with Ovharhe (2017) who discovered that there was a significant difference in property acquisition of Fadama III before and during the Fadama III project. 
Table 7. Level of respondents' property acquisition before and after the training programme with T-test result.

\begin{tabular}{|c|c|c|c|c|c|c|c|c|c|c|}
\hline & \multirow{3}{*}{ Parameters } & \multicolumn{2}{|c|}{$\begin{array}{l}\text { T-test for equality } \\
\text { of variances }\end{array}$} & \multicolumn{7}{|c|}{ T-test for equality of means } \\
\hline & & \multirow[t]{2}{*}{$\mathrm{F}$} & \multirow[t]{2}{*}{ Sig. } & \multirow[t]{2}{*}{$\mathrm{T}$} & \multirow[t]{2}{*}{ Df } & \multirow[t]{2}{*}{ Sig. } & \multirow{2}{*}{$\begin{array}{c}\text { Mean } \\
\text { Difference }\end{array}$} & \multirow{2}{*}{$\begin{array}{l}\text { Std. Error } \\
\text { Difference }\end{array}$} & \multicolumn{2}{|c|}{$\begin{array}{c}95 \% \text { Confidence Interval } \\
\text { of the Difference }\end{array}$} \\
\hline & & & & & & & & & Lower & Upper \\
\hline \multirow[t]{2}{*}{ No. of tractor } & Equal variances assumed & .592 & .443 & .384 & 166 & .702 & .01190 & .03101 & -.04931 & .07312 \\
\hline & Equal variances not assumed & & & .384 & 163 & .702 & .01190 & .03101 & -.04932 & .07313 \\
\hline \multirow[t]{2}{*}{ No. of litter used } & Equal variances assumed & 25.164 & .000 & -5.815 & 166 & $.000^{*}$ & -2.77381 & .47697 & -3.71552 & -1.83210 \\
\hline & Equal variances not assumed & & & -5.815 & 141.5 & $.000 *$ & -2.77381 & .47697 & -3.71672 & -1.83090 \\
\hline \multirow[t]{2}{*}{ Total bag of feed } & Equal variances assumed & 13.491 & .000 & -2.148 & 166 & $.033^{*}$ & -1.42857 & .66511 & -2.74173 & -.11541 \\
\hline & Equal variances not assumed & & & -2.148 & 134. & $.034^{*}$ & -1.42857 & .66511 & -2.74403 & -.11312 \\
\hline \multirow[t]{2}{*}{ Total farm size } & Equal variances assumed & .532 & .467 & -.765 & 166 & .446 & -.08333 & .10900 & -.29853 & .13186 \\
\hline & Equal variances not assumed & & & -.765 & 166 & .446 & -.08333 & 10900 & -.29853 & .13186 \\
\hline \multirow[t]{2}{*}{ Amount of egg } & Equal variances assumed & .124 & .725 & -.259 & 166 & .798 & -69048 & 2.69596 & -6.01327 & 4.63232 \\
\hline & Equal variances not assumed & & & -.259 & 165. & .798 & -.69048 & 2.69596 & -6.01344 & 4.63249 \\
\hline \multirow[t]{2}{*}{ No. of birds } & Equal variances assumed & 3.236 & .074 & -7.216 & 166 & $.000 *$ & -151.9167 & 21.05199 & -193.4808 & -110.3525 \\
\hline & Equal variances not assumed & & & -7.216 & 158 & $.000^{*}$ & -151.9167 & 21.05199 & -193.4953 & -110.3380 \\
\hline \multirow[t]{2}{*}{ Average income } & Equal variances assumed & 16.571 & .000 & -7.098 & 166 & $.000 *$ & -172119.1 & 24249.10 & -219995.5 & -124242.6 \\
\hline & Equal variances not assumed & & & -7.098 & 147.6 & $.000^{*}$ & -172119.1 & 24249.10 & -220039.4 & -124198.7 \\
\hline \multicolumn{11}{|c|}{$*$ Significant at two-tailed analysis $(\mathrm{p}<0.05)$} \\
\hline \multicolumn{11}{|c|}{ ble 8. Constraints facing the respondents. } \\
\hline \multicolumn{3}{|c|}{ Constraints } & Very & \multicolumn{2}{|c|}{ Serious (3) } & fairly & Not & Total & Mean & Rank \\
\hline \multicolumn{3}{|c|}{ Inadequate provision of starter packs to trainees by sponsors } & $22(88)$ & \multicolumn{2}{|c|}{$25(81)$} & $25(100)$ & $10(10)$ & 279 & 3.3 & $1^{\text {st }}$ \\
\hline \multicolumn{3}{|c|}{ Short training duration } & $18(72)$ & \multicolumn{2}{|c|}{$29(87)$} & $25(100)$ & $12(12)$ & 271 & 3.2 & $2^{\text {nd }}$ \\
\hline \multicolumn{3}{|c|}{ Poor electricity supply } & $25(100)$ & \multicolumn{2}{|c|}{$25(75)$} & $26(52)$ & $8(8)$ & 235 & 2.8 & $3^{\text {rd }}$ \\
\hline \multicolumn{3}{|c|}{ Poor time management during Training } & $21(84)$ & \multicolumn{2}{|c|}{$26(78)$} & $25(50)$ & $12(12)$ & 224 & 2.7 & $4^{\text {th }}$ \\
\hline Insufficient accon & modation for staff & & $17(68)$ & 28( & & $30(60)$ & $9(9)$ & 221 & 2.6 & $5^{\text {th }}$ \\
\hline Environmental sa & nitation & & $17(68)$ & 23( & & $30(60)$ & $14(14)$ & 211 & 2.5 & $6^{\text {th }}$ \\
\hline Incompetent trail & ers & & $11(44)$ & 27( & & $36(72)$ & $10(10)$ & 207 & 2.4 & $7^{\text {th }}$ \\
\hline Leadership ineffi & iency of management & & $2(8)$ & 27( & & $49(98)$ & $6(6)$ & 193 & 2.3 & $8^{\text {th }}$ \\
\hline
\end{tabular}




\section{Hypotheses Testing}

Firstly, results in Tables 9 shows that there is a significant relationship between some socio-economic characteristics of the respondents and the level of satisfaction derived from the training programme. This F-stat (2.314) implies that the variables included in the model are well fit with the dependent variable. $\mathrm{R} 2=$ 0.524 implies that a $52.4 \%$ variable in the level of training satisfaction is accounted for by the change in some socioeconomic status of respondents. The age, marital and farming experience status of the respondents were satisfactorily significant $(p<0.05)$.

Table 9. Socio-economic characteristics (Independent variable) regression Summary.

\begin{tabular}{|c|c|c|c|c|c|}
\hline \multirow{2}{*}{ Model } & \multicolumn{2}{|c|}{ Unstandardized Coefficients } & \multirow{2}{*}{$\frac{\text { Standardized Coefficients }}{\text { Beta }}$} & \multirow[b]{2}{*}{$\mathrm{T}$} & \multirow[b]{2}{*}{ Sig. } \\
\hline & $\mathrm{B}$ & Std. Error & & & \\
\hline (Constant) & 25.892 & 1.988 & & 13.023 & .000 \\
\hline Age & .025 & .058 & 0.69 & .420 & $.035^{*}$ \\
\hline Gender & .111 & .756 & .018 & .146 & .084 \\
\hline Marital Status & .156 & .174 & .107 & .898 & $.037^{*}$ \\
\hline Educational level & .153 & .383 & .048 & .400 & .099 \\
\hline Farming Experience & .232 & .075 & -.064 & 1.422 & $.047^{*}$ \\
\hline
\end{tabular}

$\mathrm{R}=0.655, \mathrm{R}^{2}=0.524$ adj. R2=0.512 with F-stat= 2.314. Note: Satisfaction (Dependent variable)* Significant @ 0.05

Table 10. Property acquired before and after the training programme.

\begin{tabular}{|c|c|c|c|c|c|}
\hline Properties acquired & $\begin{array}{c}\text { Before } \\
\text { Training } \\
\text { Programme }\end{array}$ & $\begin{array}{c}\text { After } \\
\text { Training } \\
\text { Programme }\end{array}$ & $\begin{array}{l}\text { Difference } \\
\text { (d) }\end{array}$ & $\begin{array}{l}\text { Rank } \\
\text { of } \\
\text { (d) }\end{array}$ & $\begin{array}{c}\text { The absolute } \\
\text { sum of negative } \\
\text { ranks (T) }\end{array}$ \\
\hline \multicolumn{6}{|l|}{ Farm Assets Acquired } \\
\hline Number of knapsack sprayers & 145 & 280 & -135 & -5 & 5 \\
\hline Numbers of record books & 118 & 216 & -98 & -3 & 3 \\
\hline Number of cutlasses & 461 & 787 & -326 & -8 & 8 \\
\hline Number of drums & 258 & 448 & -190 & -6 & 6 \\
\hline Number of heat sources & 1018 & 1447 & -429 & -9 & 9 \\
\hline Number of feeder trays & 3790 & 8379 & -4589 & -10 & 10 \\
\hline Number of drinker cans & 3856 & 8676 & -4820 & -11 & 11 \\
\hline Number of tractors & 4 & 3 & 1 & -14 & 14 \\
\hline Number of litters used & 228 & 461 & -233 & -7 & 7 \\
\hline \multicolumn{6}{|l|}{ Farm Inputs Acquired } \\
\hline Used bags of feed & 106 & 226 & -120 & -4 & 4 \\
\hline Total farm size (Ha) & 119 & 126 & -7 & -1 & 1 \\
\hline \multicolumn{6}{|l|}{ Farm Yields } \\
\hline Total numbers of eggs produced & 599 & 617 & -18 & -2 & 2 \\
\hline Total numbers of birds produced & 18430 & 31191 & -12761 & -12 & 12 \\
\hline \multicolumn{6}{|l|}{ Financial Capital } \\
\hline The average income per annum & $16,636,000$ & $31,094,000$ & $-14,458,000$ & -13 & 13 \\
\hline
\end{tabular}

Note: Using Wilcoxon Test, $\mathrm{Z} \mathrm{cal}=3.30, \mathrm{Z}$ tab at $0.05(5 \%)=1.65$; On the 14 items tested is equal to 21

\section{CONCLUSION AND RECOMMENDATIONS}

Based on the finding of this research, the impacts of the training programme were mostly on male youths as beneficiaries. The training programme for poultry farmers by Obasanjo Farms Nigeria Ltd had a great impact on the farmers in the following ways such as an 
increase in knowledge of feeds formulation, poultry housing, stocking and brooding techniques with an increase in the property acquired by the farmers after the training programme as outcomes of technology implementation. The major constraint which faced the farmers upon graduation from the training was the inadequate provision of starter packs by various sponsors.

The findings of this study led to the following recommendations:

- that both the government and private extension agencies should be empowered for effective discharge of duties in information dissemination

- donors should endeavor to provide starter packs to clientele upon graduation in training programmes to increase their motivations

- poultry farm automation should be included in the training curriculum

\section{ACKNOWLEDGMENTS}

In the course of getting this research work accomplished. The following contributors are hereby acknowledged: Mr. Alli Folorunsho and other field enumerators who administered the questionnaire, Dr. R. A. Isiorhovoja who assisted in the statistical analysis, Mr. Obinna Apugo who was the information technology analyst and the Delta State University, Asaba campus lecturers who ignited my zeal to research and publish. The head of the department, Prof. Chukwuji, C. is not left out because he gave the ethical approval for the conduct of this research. Besides, the various authors cited are also acknowledged.

\section{REFERENCES}

Agbamu, J. U. 2006. Essentials of Agricultural Communication in Nigeria. Lagos: Malthouse Press, pp. 21-34.

Agbamu, J. U. and G. O. Okagbare. 2005. Institutional Strengthening of Ogun State Agricultural Development Programme upon Expiration of World Bank Assistance. pp.322-25.

Aromolarun, 0. 1999. Analysis of household preferences and determinants in the consumption of meat. Available at http://www.afriabib.org/irrd15/ades1510.htm.

Delta State. 2018. Delta State. Available at http://en.m.wikipedia.org/wiki/deltastate.
Ebewore, S. O. and O. J. Ovharhe. 2019. Farmers' Access to Adoption of the Internet as Source of Agricultural Information in Delta State, Nigeria. Taraba Journal of Agricultural Research, 6: 12-20.

FAO. 2002. The planning for effective training. Rome. Available at http://www.fao.org/publications/sofa/en/.

Gbigbi, M. T. and O. J. Ovharhe. 2016. Constraints to Adoption of New Technologies by Small Scale Farmers in Bomadi Local Government Area of Delta State, Nigeria. Nigerian Journal of Farm Management, 15: 22-23.

I-Project. 2015. Problems associated with small scale poultry farms in COBEN school farms of Ovia North East Local Government Area Edo State.

Japan International Cooperation Agency. 2008. Agricultural Extension Methodology (JICA) 32pp.

Leagans, J. P. 1990. Characteristics of teaching and learning in extension education. Division of Agricultural Extension, ICAR, New Delhi - 12, pp. 73-78.

Oghenero, J. O., A. Felix Odemero, O. Goddey Folunsho and J.-J. Uduak Oghenefejiro. 2020. Appraisal of backyard farming among households: Implications for rural development and food security in Nigeria. Asian Journal of Agriculture and Rural Development, 10: 160-70.

Ovharhe, O. and M. Gbigbi. 2016. Socio-economic Determinants of Youth Empowerment by Fadama III Project in Delta State, Nigeria: Implications for Agricultural Transformation. International Journal of Agricultural Extension and Rural Development Studies, 3: 12-20.

Ovharhe, O. J. 2017. Evaluation of the Performance of Fadama III agricultural projects in the Niger Delta Area, Delta State University, Abraka, Nigeria.

Ovharhe, O. J., P. Emaziye and G. F. Okwuokenye. 2020. Farmers' satisfaction with agricultural extension services in Delta State, Nigeria. . International Journal of Agricultural Technology, 16: 1463-74.

Ovwigho, B. 0. 2013. Effects of Advisory Services on Attitude to Innovations and Fatalism: A Case Study of the Fadama III Participants in Delta Central Senatorial District of Delta State Nigeria. Journal of Educational and Social Research.

Raheem, 0. A. 2011. Poultry farmers' awareness and knowledge of improved production practices. Available at unaab.edu.ng/index.php/article id. 
Rielly, B. 2013. Training Administrators for Development London Heinemann Publishers pp. 50-55.

Sanoria, Y. C. 2011. Extension Education, Shree Lakshmi Press, Baptala pp. 70-74.

Uzokwe, U. N. and O. J. Ovharhe. 2011. Assessment of Participatory Tools Used by Agricultural Extension Agents in Delta State ADP. International
Journal of Agricultural and Development Economics, 1: 39-48.

World Bank. 2010. Getting Agriculture Going in Nigeria: Institutionalizing Impact Evaluation within the Framework of Monitoring and Evaluation System accessed on January 6th, 2012. Washington DC: Available at www.worldbank.org.

Publisher's note: EScience Press remains neutral with regard to jurisdictional claims in published maps and institutional affiliations.

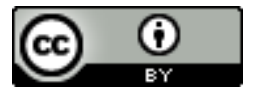

Open Access This article is licensed under a Creative Commons Attribution 4.0 International License, which permits use, sharing, adaptation, distribution and reproduction in any medium or format, as long as you give appropriate credit to the original author(s) and the source, provide a link to the Creative Commons license and indicate if changes were made. The images or other third-party material in this article are included in the article's Creative Commons license, unless indicated otherwise in a credit line to the material. If material is not included in the article's Creative Commons license and your intended use is not permitted by statutory regulation or exceeds the permitted use, you will need to obtain permission directly from the copyright holder. To view a copy of this license, visit http://creativecommons.org/licenses/by/4.0/. 